\title{
GPI wt Allele
}

National Cancer Institute

\section{Source}

National Cancer Institute. GPI wt Allele. NCI Thesaurus. Code C50381.

Human GPI wild-type allele is located in the vicinity of 19q13.1 and is approximately $35 \mathrm{~kb}$ in length. This allele, which encodes glucose-6-phosphate isomerase protein, is involved in the reversible isomerization of glucose-6-phosphate and fructose-6-phosphate.

Defects in the GPI gene cause congenital nonspherocytic hemolytic amemia. 